\title{
An Effect Analysis of Company's Size, Profitability, and Age towards Islamic Social Reporting Disclosure and Company's Valuation
}

\author{
Bambang Widagdo \\ University of Muhammadiyah Malang \\ bwidagdo@gmail.com
}

\author{
Novita Satiti \\ University of Muhammadiyah Malang \\ satiti.umm@gmail.com
}

\begin{abstract}
There is a principle of public needs that deals with the prevention of damage and poverty by the Corporate Social Responsibility actions. The objectives of this research were to analyze: the effect of company's size, profitability and age against the disclosure of Islamic Social Reporting (ISR); the presence of effect of company's size, profitability and age against company's valuation. It also aims to find out: the impact of ISR against the company's valuation; the effect of company's size, profitability and age against the company's valuation through the disclosure of ISR. Based on the analysis results, it was found that the company's size and age simultaneously have brought significantly positive effects towards the disclosure of ISR; while profitability does not contribute any significant effect towards the disclosure of Islamic Banks Indonesia's ISR. The company's size and age partially have brought significant effects towards company's valuation; while profitability and disclosure of ISR do not give any significant effect on company's valuation.
\end{abstract}

Keywords - company size, profitability, age, Islamic Social Reporting disclosure, company's valuation.

\section{INTRODUCTION}

Islamic bank in Indonesia experiences significant development after the passing of Constitutions number 21, 2008 about Islamic banking. The increasing development is accompanied by fierce competition that forces Islamic banks to improve their services. The biggest challenge for Islamic banks nowadays is to keep their stakeholders' trust because the trust can give significantly positive effects on the development of the respective Islamic banks.

Islamic banking and social responsibility is relevant to be discussed considering the following factors: Islamic banking is based on the Islamic principles, which demand them to operate within the moral, ethical, and social responsibilities. Furthermore, there are also the principles of social needs, which concern on the prevention of damage and poverty [1].

CSR disclosure by Islamic banks is performed to achieve three objectives; to show conformity to Islamic principles, especially in regards to transaction involving other parties, to show the operation of business affecting immediate community, and finally to help Muslims to perform their religious duties [2]. The disclosure of CSR of Islamic banks holds an important role as it provides information related to organizational or company's ethical responsibilities to the interest holders and help them to make decision [3].

Research about factors that influence the disclosure of ISR has been previously conducted and has resulted in diverse results. One of the factors which is assumed to influence the disclosure of ISR is bank's size that has given significantly positive effect on the disclosure of ISR by [4], so does with the other research by [5]. Previous research has proven that the degree of company's disclosure rises as the profitability of the company rises. Profitability contributes positively to the disclosure of ISR. However, the other research found that profitability does not give any significant effect on the disclosure of ISR [6].

This paper presents a result of effects with some combines aspects from the previous researches by investigating some impact factors ISR disclosure, which has not been observed [4], [5], and [6]. The authors add stock value factor which is estimated as the impact factor of ISR disclosure. Based on this difference, it has been believed that the obtained result can contribute valuable information and new understanding which can give additional benefits for investors, customers, regulators, companies, and other readers.

\section{METHOD}

This was a quantitative research. Documentary data is in the form of annual report of Islamic banks in Indonesia. Dependent variable research was the scores obtained from analysis of disclosure level of ISR. The ISR index became 48 items which then were categorized into six themes; finance investment, product/ service, employees, community, environment, and company's management [4]. The second dependent variable was the company's valuation. The company's valuation shows quality of company in the eyes of the public. Therefore, the company's valuation is shown in the stock book value.

There were three independent variables in this research namely; company's size, profitability, and age. The size of company was proxied with bank's total asset 
acquired from annual final financial report. Profitability ratio in this research is using ROA for the fit profitability analyzed. Company's age is used to measure the effect of company's operational duration. The population of this research is Indonesian Islamic Bank's during 2011 to 2016. The samples were taken using purposive sampling method. Data source in this research was in the form of secondary data which is annual reports of commercial Islamic Banks.

\section{RESULT}

The testing of direct influence was performed by analyzing the significance of $\mathrm{T}$-statistics value of exogenous variables against the endogenous variables. If the value of T-statistics $<$ critical value $(\alpha=5 \%)$ which is 1.96 , it can be said that there has been a significant effect of exogenous variables against the endogenous ones. Hypothesis testing on the effects of exogenous variables against endogenous variable of ISR.

The result of direct effect path co-efficient calculation of exogenous variables against endogenous variables 'attitude' is presented in Table 1. The testing result of the effects of company's size against ISR has shown Tstatistics value of 15.049. If the value of T-statistics > critical point, therefore it can be assumed that there has been a significant effect of company's size towards ISR. Coefficient value at positive 1.041 indicates that the relation of the two variables is in the same direction and significant, meaning that the bigger the size of a company is, the better the social disclosure of the bank and the more in line the bank with the Islamic sharia principals.

The testing result of the effects of profitability against ISR has shown that T-statistics value is at 0.083 . If Tstatistics value is compared to the critical point value, it can be seen that the T-statistics value < critical point. It can be assumed that there has not been any significant effect contributed by profitability towards the ISR.

Coefficient value at -0.002 suggests that the relation between two variables is not in the same direction and not significant, meaning that if profitability of a bank increases or decreases, it will not affect the social disclosure of the bank, even though there is a tendency in which if a decrease of profitability occurs, there will be an increase of social disclosure which is in accordance with the Islamic principles adopted by the bank.

The testing result Table1. of the effects of company's age against ISR has shown the T-statistics value of 16.559. If the value of $\mathrm{T}$-statistics > critical point, therefore it can be concluded that there has been a significant effect contributed by company's age against the ISR. Coefficient value at positive 0.449 indicates that the two variables are in the same direction and significant, meaning that the older the company is, the better the social disclosure of the bank and the more it is in accordance with the Islamic principles.

Hypothesis testing on the effects of exogenous variables against endogenous variable of 'Adoption Intention'.
Table 1. Result of Exogenous Variables

\begin{tabular}{lccc}
\hline $\begin{array}{l}\text { Exogenous } \\
\text { variables }\end{array}$ & Path Coeff. & T-Statistc & Descriptions \\
\hline Size & 0.449 & 15.049 & Sig \\
Profitability & -0.002 & 0.083 & Not Sig \\
$\quad$ Age & 1.041 & 15.049 & Sig \\
\hline
\end{tabular}

The calculation result of direct path coefficient of exogenous variables against endogenous variables 'Adoption Intention' is presented in the Table 2. The testing result of the effects of the company's size against the company's valuation has shown T-statistics value of 16.559. If the value of T-statistics > critical point, there has been a significant effect contributed by the company's size towards the company's valuation. Coefficient value at positive 0.655 indicates that the two variables are in the same direction and significant, meaning that the bigger the size of the company is, the higher the company's valuation.

Table 2. Result of Direct Path coefficient of Exogenous against Endogenous Variables

\begin{tabular}{lcrl}
\hline $\begin{array}{l}\text { Exogenous } \\
\text { Variables }\end{array}$ & Path Coef. & T-statistics & Description \\
\hline Size & 0.655 & 5.316 & Sig \\
Profitability & 0.082 & 1.110 & Not Sig \\
Age & 0.576 & 2.706 & Sig \\
ISR & -0.156 & 0.645 & Not Sig \\
\hline
\end{tabular}

The testing result of the effects of profitability against the company's valuation has shown T-statistics value of 1.11. If the value of $\mathrm{T}$-statistics is compared to the critical point value, it can be portrayed that the value of T-statistics < critical point. Therefore, it can be concluded that there has not been any significant effects contributed by profitability towards the company's valuation.

Coefficient value at positive 0.082 indicates that the two variables are in the same direction but not significant, meaning that if the profitability of a bank rises or falls, it will not contribute any significant impact towards the company's valuation, even though there is a tendency that if profitability increases, so will the company's valuation.

The effects of company's age against the company's valuation are indicated in T-statistics value of 16.559. If the T-statistics > critical point, therefore it can be assumed that there has been a significant effect contributed by the company's age towards the company's valuation. Coefficient value at positive 0.576 shows that the two variables are in the same direction and significant, meaning that the younger the age of the bank, the lower its company's valuation will be. 
ISR effect on the company's valuation is projected in $\mathrm{T}$-statistics value of 0.64 . If the $\mathrm{T}$-statistics value < critical point, there has not been any significant effects contributed by ISR towards the company's valuation. Coefficient value at -0.156 (negative) indicates that the two variables are in the opposite direction and are not significant, meaning that if the ISR of a bank rises or decreases, it will not affect the valuation of the bank, even though there is a tendency that if ISR decreases, the company's valuation will increase accordingly.

Indirect effect is an effect which is measured indirectly in one variable to another by means of proxy variable. The indirect effect coefficient is obtained from the multiplication of both direct effects and is considered significant if both direct effects are significant. If one or both of the direct effect coefficients is non-significant, the indirect effect coefficient is also non-significant. There were three indirect effects tested in this current research as presented in the Table 3 .

Table 3. Indirect Effect Result

\begin{tabular}{|c|c|c|c|c|}
\hline $\begin{array}{l}\text { Indirect } \\
\text { Effect }\end{array}$ & $\begin{array}{l}\text { Direct Effe } \\
\text { Coefficient }\end{array}$ & & $\begin{array}{l}\text { Indirect } \\
\text { Effect } \\
\text { Coeff. }\end{array}$ & $\begin{array}{l}\mathrm{T}- \\
\text { statistics }\end{array}$ \\
\hline $\begin{array}{l}\mathrm{SIZE} \rightarrow \\
\mathrm{ISR} \rightarrow \\
\mathrm{NP}\end{array}$ & $\begin{array}{l}\text { SIZE } \rightarrow \text { ISR }= \\
0.449 *\end{array}$ & $\begin{array}{l}\mathrm{ISR} \rightarrow \mathrm{NP} \\
=-0.156^{\mathrm{ns}}\end{array}$ & $\begin{array}{c}- \\
0.07011\end{array}$ & 0.644 \\
\hline $\begin{array}{l}\mathrm{ROA} \rightarrow \\
\mathrm{ISR} \rightarrow \\
\mathrm{NP}\end{array}$ & $\begin{array}{l}\mathrm{ROA} \rightarrow \mathrm{ISR}= \\
-0.002^{\mathrm{ns}}\end{array}$ & $\begin{array}{l}\mathrm{ISR} \rightarrow \mathrm{NP} \\
=-0.156^{\mathrm{ns}}\end{array}$ & 20.000 & 0.086 \\
\hline $\begin{array}{l}\mathrm{AGE} \rightarrow \\
\mathrm{ISR} \rightarrow \\
\mathrm{NP}\end{array}$ & $\begin{array}{l}\mathrm{AGE} \rightarrow \mathrm{ISR}= \\
1.041^{*}\end{array}$ & $\begin{array}{l}\mathrm{ISR} \rightarrow \mathrm{NP} \\
=-0.156^{\mathrm{ns}}\end{array}$ & $\begin{array}{c}- \\
0.16249\end{array}$ & 0.644 \\
\hline
\end{tabular}

The indirect effect contributed by the company's size towards the company's valuation through ISR is found from the multiplication result of direct effect contributed by the company's size towards ISR and the direct effect of ISR against the company's valuation. Therefore, the indirect effect value is $0.449 \mathrm{x}-0.156=-0.0701$.

Direct effect testing employed sobel test and it has been found that the T-statistics value of the calculation result using sobel formula is 0.644 . The value is smaller compared to the critical point value; it can be assumed that there has not been any significant effect contributed by the company's size towards the company's valuation through ISR.

The indirect effect of profitability against the company's valuation through ISR is found from the multiplication result of direct effect profitability against ISR and the direct effect of ISR against the company's valuation. Therefore, the acquired indirect effect value is $-0.002 \times-0.156=0.00029$. From the indirect effect testing using sobel test, the T-statistics value of calculation result formula is 0.086 , which is smaller compared to the critical point value, it can be concluded that there have not been any significant effects contributed by profitability against the company's valuation through ISR.
The indirect effect of the company's age towards the company's valuation through ISR is found from the multiplication result of direct effect between the company's age against ISR and the direct effect of ISR against the company's valuation. The acquired indirect effect is $1.041 \mathrm{x}-0.156=-0.16249$. From the indirect effect testing using sobel test, the T-statistics value of calculation formula is .644. The value is smaller compared to the critical point value, it can be concluded that there has not been any significant effects contributed by the company's age against the company's valuation through ISR.

\section{CONCLUSION}

Based on the content analysis of ISR disclosure of commercial Islamic banks in Indonesia during 2011 to 2016 period, bank's size and age simultaneously contribute to give positive effects on the disclosure of Islamic Social Reporting; while profitability does not contribute any significant effects towards the disclosure of Islamic Social Reporting of Islamic banks in Indonesia. The size and age of bank have partially contributed positive effects on the company's valuation; while profitability and disclosure of Islamic Social Reporting do not contribute any significant effects on the company's valuation.

\section{REFERENCES}

[1] Dusuki, A. W., \& Dar, H. Stakeholders' Perceptions of Corporate Social Responsibility of Islamic Banks: Evidence from Malaysian Economy. International Conference on Islamic Economics and Finance, 2005.

[2] Maali, B., Carson, P., \& Napier, C. Social Reporting by Islamic Banks. Abacus, Vol. 42, No.2, 266-289, 2006

[3] Hassan, A., \& Harahap, S. Exploring Corporate Social Responsibility Disclosure: The Case of Islamic Banks. International, 2010.

[4] Othman, R., Thani, A., \& Ghani, E. Determinants of Islamic Social Reporting Among Top ShariaApproved Companies in Bursa Malaysia. Research Journal of International Studies, 2009.

[5] Lucyanda, Jurica dan Lady Gracia Prilia Siagian, The Influence of Company Characteristics Toward Corporate Social Responsibility Disclosure. International Conference on Business and Management, Phuket-Thailand...p.601-619, 2012

[6] Iswandika, Ryandi et al.. "Pengaruh Kinerja Keuangan, Corporate Governance, dan Kualitas Audit terhadap Pengungkapan CSR, Jurnal Akuntansi Universitas Trisakti, Volume 1 No.2. p.1$18,2014$. 